\title{
EMISSION OF FUMES OF URSUS MF235 UNDER CONDITIONS OF LOAD WITH THE USE OF A MOVABLE DYNAMOMETRIC STAND
}

\author{
Andrzej Kuranc ${ }^{*}$, Tomasz Słowik, Paweł Krzaczek, Grzegorz Maj \\ Department of Power Industry and Transport Means, University of Life Sciences in Lublin \\ *Corresponding author: andrzej.kuranc@up.lublin.pl
}

\begin{tabular}{|c|c|}
\hline ARTICLE INFO & ABSTRACT \\
\hline $\begin{array}{l}\text { Article history: } \\
\text { Received: August } 2016 \\
\text { Received in the revised form: } \\
\text { September } 2016 \\
\text { Accepted: October } 2016 \\
\end{array}$ & \multirow{2}{*}{$\begin{array}{l}\text { The article presents calculations of unit fumes emission made based } \\
\text { on the measurements of the fumes composition during a load test. The } \\
\text { test was carried out with the use of a movable dynamometric stand } \\
\text { adjusted for testing agricultural tractors by power take-off shaft. } \\
\text { Calculations of unit emission were made based on the assumed flow } \\
\text { of air sucked by an engine and the measured composition of fumes } \\
\text { emitted during the load test. Results of tests and analyses supply } \\
\text { information on the mass of particle matter and the selected gas ele- } \\
\text { ments emitted by an engine working under the load which was related } \\
\text { to simultaneous determination of the exploitation characteristic of an } \\
\text { engine. The presented methodology may be helpful at evaluation of } \\
\text { impact of farm tractors on the environment within the hazardous fume } \\
\text { components emitted by them. }\end{array}$} \\
\hline $\begin{array}{l}\text { Key words: } \\
\text { emission of fumes, } \\
\text { farm tractor, } \\
\text { load test of an engine, } \\
\text { movable dynamometer }\end{array}$ & \\
\hline
\end{tabular}

\section{Introduction}

The tests on a combustion engine used in agricultural vehicles include operations which enable assessment of the technical condition and the functioning of an engine and its influence on environment (Contributors, 2009). A lot of attention has been paid to biofules and exploitation parameters of engines supplied with these fuels (Krzaczek, 2009; Osipowicz and Stoeck, 2014). Mainly, dynamic parameters are analysed such as engine torque and mechanical power but also many tests carried out in the aspect of impact of such engines on the environment particularly with emission of hazardous fume components (Ambrozik et al., 2015; Kuranc, 2015; Merkisz et al., 2013).

Systems, which directly determine the efficiency of combustion engine operation are: crank and piston system, timing gear system, loading system, fuel apparatus and control system. A functional assessment of these systems may be carried out with various methods. In the exploitation practice of farm tractors four main groups of tractor research methods are applied. The first group consists of methods which use evaluation of working factors parameters such as: fuel, air, fumes, smearing factor, cooling factor. The second group comprises methods consisting in testing parameters related to energy condition of an engine such as: torque, power, rotational speed or fuel consumption (Krzaczek, 2009; Podstanicky et al., 2005). The third group concerns analysis of physical quantity fields distribution such as: temperature or vibrations of engine components or noise generated by them. 
The fourth group consists of disassembly methods which enable direct evaluation of the wear degree and verification of particular parts of an engine (Piekarski, 1997).

Evaluation of the technical condition of en engine is required most often during exploitation of an engine. Often, these situations come down to decrease of engine power during field works. Such circumstances may result from various reasons. Moreover, the initial and superficial assessment made by a user does not have to be accurate. In such a case, fast and non-disassembly engine tests, which can be carried out in a farm, are desirable. A movable dynamometric stand is an example of an apparatus used in this type of research. Such types of movable dynamometers are more popular. Except for the control of torque and power they enable realization of tests enabling simulation of load states of a tractor engine close to ones which take place at various agrotechnical treatments. This stand may be also used during research on the emission of fumes during load tests. Data obtained in such tests, such as exploitation characteristics of the maximum power and maximum torque supplied with information on unit emission of particular elements of fumes may be helpful at creating a database on farm tractors on a given area. They may be next used for estimation of emission on the selected cultivation areas including type of crops, agrotechnical treatments and the used machinery park (Koniuszy, 2008).

Analysis of present trends with regard to fumes emission is accompanied by observation of many changes concerning measurement methods and conditions of research. Emission of particle matter PM is very important from the point of view of harmfulness for human health but their mass, number and distribution of size is crucial, which is indicated by authors of many papers (Health Effects Institute, 1995; Pośniak et al., 2010). Moreover, tests in conditions of real exploitation of vehicles with the use of a movable emission measurement system PEMS are of great interest (Gallus et al., 2016; Huang et al., 2013; Merkisz et al., 2013).

\section{The objective and scope of research}

The objective of the paper was to determine unit emission of the selected fumes elements during simulation of load conditions which take place during difficult field works.

Loads were placed while exploitation characteristics was carried out, which is made analogically to external characteristics. However, non individual regulation of fuel apparatus of an engine is included.

The scope of research included measurement and registration of ecological and energy parameters of an engine:

- torque measured at power take-off shaft of an engine $-\mathrm{M}_{\mathrm{oWOM}},(\mathrm{Nm})$

- rotational speed measured at power take-off shaft of an engine $-\mathrm{n}_{\mathrm{WOM}},\left(\mathrm{min}^{-1}\right)$

- rotational speed of an engine $-\mathrm{n},\left(\mathrm{min}^{-1}\right)$

- temperature of engine oil $-\mathrm{T},\left({ }^{\circ} \mathrm{C}\right)$

- emission of particle matter - PM (Particle Matter), $\left(\mathrm{mg} \cdot \mathrm{m}^{-3}\right)$

- volumetric participation of gas components of fumes $-\mathrm{CO}, \mathrm{CO}_{2}, \mathrm{O}_{2},(\%)$ and $\mathrm{HC}, \mathrm{NO}_{\mathrm{X}}$, (ppm)

Then, by means of calculations unit emissions of the selected elements of fumes were determined. 
Emission of fumes...

\section{Methods of research}

URSUS MF 235 equipped with AD3.152 engine with self-ignition and run of $554 \mathrm{mth}$ was the object of research (ZPC URSUS, 1987).

Devices by MAHA Maschinenbau Haldenwang GmbH \& Co constituted test apparatus KG: mobile dynamometer stand ZW500, fumes analyzer MGT5 and particle matter emission measurement device MPM4.

Mobile dynamometer stand ZW500 type (Fig. 1) designed for research of farm tractors engine by the power take-off shaft. The device is equipped with electronically controlled eddy-current brakes mounted on the trailer frame which enables movement to the place where tests are carried out. Basic data of the stand were presented in table 1.

Table 1

Basic technical data of a tractor dynamometer ZW500

\begin{tabular}{ll}
\hline Maximum control of rotational speed (direct drive) & $2500 \mathrm{~min}^{-1}$ \\
Maximum power collected by brakes & $500 \mathrm{~kW}$ \\
Maximum torque & $6600 \mathrm{Nm}$ \\
Electronic measuring system. & DMS technology \\
Supply & $400 \mathrm{~V}, 50 / 60 \mathrm{~Hz}, 16 \mathrm{~A}$ \\
Weight (with a trailer) & $1300 \mathrm{~kg}$ \\
Rated current & $15 \mathrm{~A}$ \\
\hline
\end{tabular}

MAHA, 2006

Fume analyser MGT5 (MAHA, 1999) which meets the requirements of the 0 class analysers was used for the research. It is a NDIR (nondispersive infrared) type analyser dedicated for the research of engines with spark ignition on account that measurement of noncombusted hydrocarbon takes place within infrared radiation suitable for hexane $\mathrm{C}_{6} \mathrm{H}_{14}$, detection of one of main components of benzine. It was assumed that combustion in diesel engine has a complete combustion nature and thus general emission of hydrocarbons is low and error related to the measurement of their participation is not significant.

MPM4 measurement device cooperates with a fume analyser. It enables measurement and registration of particle matter emission, which are a characteristic property of fumes from self-ignition engines. The measurement takes place by photometry with the use of laser light. Light stream gets to the particle matter emitted in fumes, reflects from them and gets to a detector (MAHA, 2008). The device determines the weight of particles in a capacity unit of fumes and enables measurements within 0.01 to $700.0 \mathrm{mg} \cdot \mathrm{m}^{-3}$.

Before the research was carried out, the tractor and its drive unit were inspected including the supply system, air intake system, smearing and cooling system. Exchange of filters and exploitation liquids were replaced and injection pump and injectors were controlled on a sampling table.

Then, a test stand (Fig. 1) was set and load on the power take - off shaft was placed from 0 to $250 \mathrm{Nm}$ at the rotational speed of the power take-off shaft of ca. $500 \mathrm{~min}^{-1}$. It allowed achieving a stabilized thermal condition of an engine and elements of the transference system of a drive. Initial measurements and verification of a proper functioning of measuring apparatus were carried out simultaneously. 
The scope of changes of a rotational speed of the power take-off shaft which corresponds to the exploitation scope of the rotational speed of an engine was assumed (ZPC URSUS, 1987). Changes of the rotational speed were carried out from $650 \mathrm{~min}^{-1}$ to 400 $\mathrm{min}^{-1}$, in a step change manner every $50 \mathrm{~min}^{-1}$ and the maintenance time of load in a given measuring point was $5 \mathrm{~s}$. When the dynamometer stand changes were set the braking moment and the rotational speed control were carried out automatically by an electronic control system.

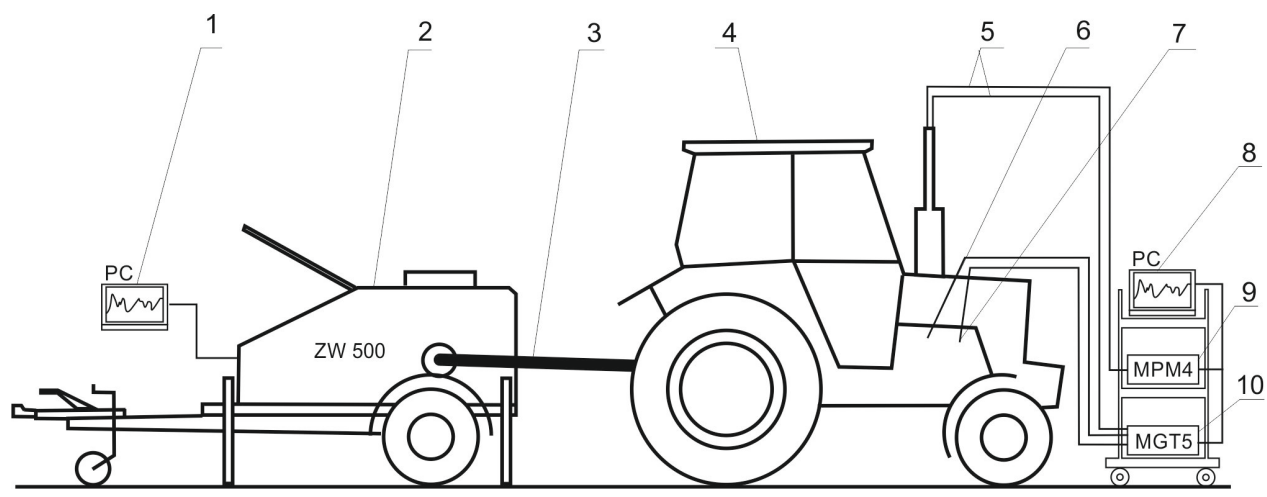

Figure 1. Schematic representation of measurement stand: 1 - controlling computer, 2 - dynamometric stand, 3 - output and acceptance shaft, 4 - object of research, 5 - fume collection conduits, 6 - temperature sensor, 7 - sensor of rotational speed, 8 - control computer, 9-particle matter measurement, 10 -fume analyser

Before the test a control pull rod which controls the injection pump operation was set in a position which corresponds to the maximum dose of fuel. Without an external load the engine developed a rotation speed of $2200 \mathrm{~min}^{-1}$. On the other hand, a shift from the first measuring point was related to the increase of the braking moment and decrease of the rotational speed. When the required speed of the power take-off shaft, which is regulated by an adjusting braking moment, was stabilized, the dynamometer stand control was placing a greater load in order to achieve the following assumed measuring point.

During determination of exploitation characteristic the weight of emitted particle matter and volumetric participations of the selected gas components $\mathrm{CO}_{2}, \mathrm{CO}, \mathrm{O}_{2}, \mathrm{HC}, \mathrm{NO}_{\mathrm{X}}$, engine oil temperature and rotational speed of an engine were measured with MPM4 measurement device which were recorded by means of MGT5 analyser.

The obtained measurement data in relation to information on the air composition and the course of the combustion reaction course (equation 1) enable determination of the exhaust gas composition of the investigated engine for given load conditions. 
Emission of fumes...

$$
\begin{aligned}
& C_{\beta} H_{\alpha} O_{\varepsilon}+\lambda \cdot\left[\left(\beta+\frac{\alpha}{4}\right)-\frac{\varepsilon}{2}\right] \cdot O_{2}+\lambda \cdot\left[\left(\beta+\frac{\alpha}{4}\right)-\frac{\varepsilon}{2}\right] \cdot \frac{78}{21} N_{2}+\lambda \cdot\left[\left(\beta+\frac{\alpha}{4}\right)-\frac{\varepsilon}{2}\right] \cdot \frac{1}{21} A r \rightarrow \\
& \rightarrow \beta \cdot \mathrm{CO}_{2}+\frac{\alpha}{2} H_{2} O+\lambda \cdot\left[\left(\beta+\frac{\alpha}{4}\right)-\frac{\varepsilon}{2}\right] \cdot \frac{78}{21} N_{2}+\lambda \cdot\left[\left(\beta+\frac{\alpha}{4}\right)-\frac{\varepsilon}{2}\right] \cdot \frac{1}{21} A r+(\lambda-1) \cdot\left[\left(\beta+\frac{\alpha}{4}\right)-\frac{\varepsilon}{2}\right] \cdot O_{2}
\end{aligned}
$$

where:

$\mathrm{C}_{\beta} H_{\alpha} O \varepsilon-$ fuel,

$\beta, \alpha, \varepsilon-$ molar relation of carbon, hydrogen, oxygen to carbon in a replacing fuel particle $C_{\beta} H_{\alpha} O \varepsilon,(\beta=1, \alpha=1.85, \varepsilon=0.005)$,

$\lambda-$ coefficient of air excess,

$\mathrm{O}_{2}, \mathrm{~N}_{2}, \mathrm{Ar}-$ selected air elements,

$\mathrm{CO}_{2}, \mathrm{H}_{2} \mathrm{O}, \mathrm{O}_{2}, \mathrm{~N}_{2}, \mathrm{Ar}-$ selected components of fumes.

However, information on volumetric participation of particular components without reference to the expense of emitted fumes is incomplete. In case of a naturally aspirated selfignition engine the air mass used in the combustion process may be determined from the following formula (2) (Dajniak, 1985; Kuszewski and Ustrzycki, 2011; Niewiarowski, 1983).

$$
q_{a i r}=\frac{V_{s s} \cdot n \cdot \eta_{v}}{\tau} \cdot \frac{p_{a t m}}{r \cdot T_{a i r}}
$$

where:

$q_{\text {air }}$ - mass air expense, $\left(\mathrm{kg} \cdot \mathrm{s}^{-1}\right)$

$V_{s s}$ - step volume of an engine, $\left(\mathrm{m}^{3}\right)$

$n \quad$ - rotational speed of a crankshaft, $\left(1 \cdot \mathrm{s}^{-1}\right)$

$\tau-$ coefficient of engine type ( $\tau=2$ - four-stroke engine)

$\eta_{v}-$ volumetric efficiency of a cylinder, (-)

$r \quad$ - individual gas constant number for air, $\left(\mathrm{J} \cdot \mathrm{kg}^{-1} \cdot \mathrm{K}^{-1}\right)$

$p_{\text {atm }}$ - atmospheric pressure, $(\mathrm{Pa})$

$T_{\text {air }}$ - supplying air temperature, $(\mathrm{K})$

Air expense described with equation (2) does not allow direct determination of fumes expense but number of gas moles after combustion were determined and then the total expense of fumes and expenses of their particular components was calculated with the use of a theoretical equation of combustion which take place in the engine (1) (Kuranc, 2015).

Based on AFR coefficient for diesel oil (14.46) and the value of air excess coefficient $\lambda$ and $\mathrm{CO}$ and $\mathrm{CO}_{2}$ emission determined for particular conditions of engine load, the mass of consumed fuel was calculated and thus hour $\mathrm{G}_{\mathrm{h}}$ and unit fuel consumption $\mathrm{g}_{\mathrm{e}}$.

\section{Results of measurements}

As a result of research which was carried out the maximum power $\mathrm{N}_{\mathrm{e}}$ and the rotational speed of en engine $\mathrm{M}_{\mathrm{o}}$ were determined. After correction according to the standard DIN 70020 after environmental parameters $\left(T_{\text {air }}=29^{\circ} \mathrm{C}, \varphi=40 \%, p_{\text {atm }}=992 \mathrm{hPa}, p_{\text {vap }}=16 \mathrm{hPa}\right)$ 
were included, without losses in the transference system of drive to the power take-off shaft are respectively $25.02 \mathrm{~kW}\left(n=2027 \mathrm{~min}^{-1}\right)$ and $142.29 \mathrm{Nm}\left(n=1400 \mathrm{~min}^{-1}\right)$.

When exploitation characteristic was determined, emission of $\mathrm{PM}, \mathrm{CO}_{2}, \mathrm{CO}, \mathrm{O}_{2}, \mathrm{HC}$, $\mathrm{NO}_{\mathrm{X}}$ and temperature of engine oil and the rotational speed of engine were registered (Fig. 2).

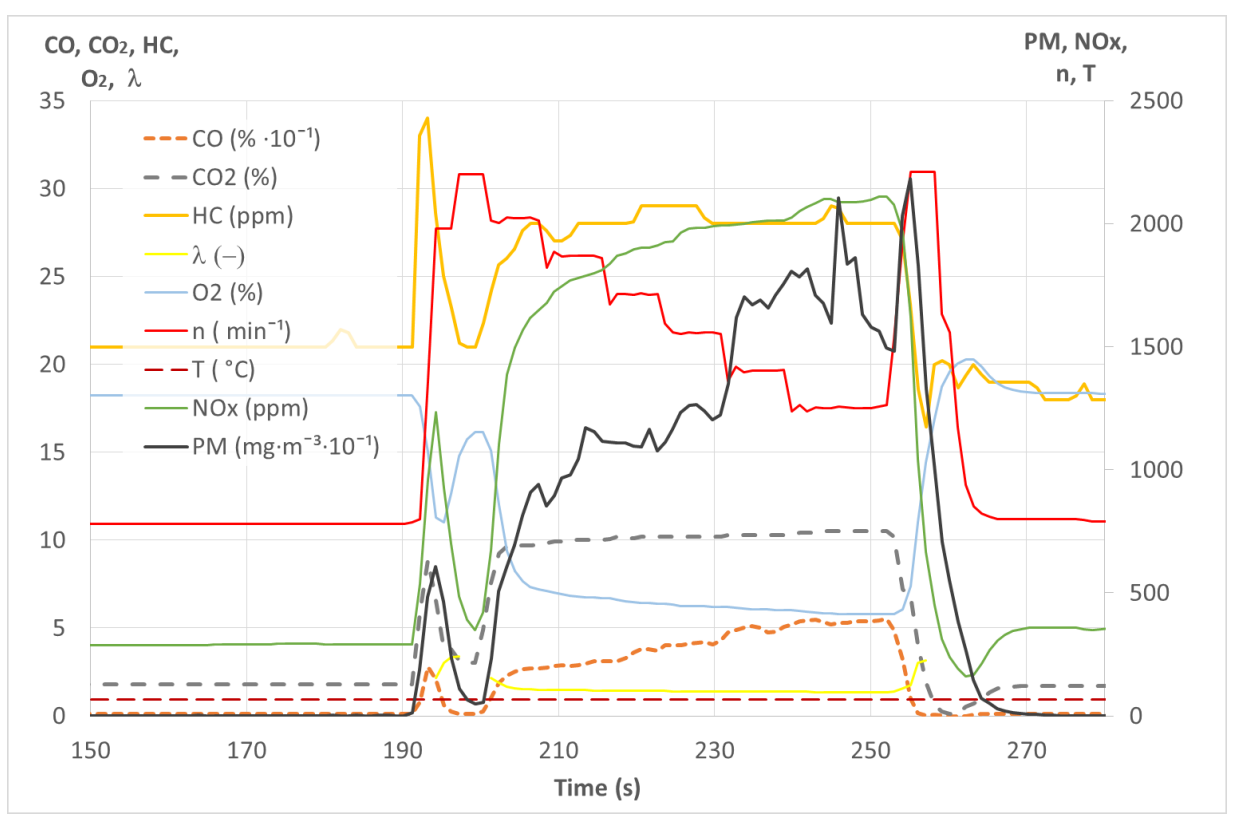

Figure 2. The course of volumetric participations of selected components of fumes of AD3.152 engine during a loading test

Analysis of the changes in fumes composition during the test proves that volumetric participation of $\mathrm{CO}, \mathrm{CO}_{2}, \mathrm{NO}_{\mathrm{x}}$ and $\mathrm{PM}$ emission demonstrate growing trends along with the increase of the engine load and decrease of its rotational speed. It is related to the deteriorating conditions of the combustion process. $\mathrm{CO}$ participation increases to the value of 0.25 to $0.58 \%, \mathrm{CO}_{2}$ participation from $9.7 \%$ to $10.5 \%$ and $\mathrm{NO}_{\mathrm{X}}$ from ca. $1600 \mathrm{ppm}$ to 2100 ppm. Only participations of HC emission have a constant level of approx. 28-29 ppm and are considerably lower than the remaining components.

The discussed measurement data (Fig.2) based on the course of combustion reaction (equation 1) allowed determination of the exhaust fumes composition both without loading and under loading, which occurs in case of hard field works which is illustrated by a circle diagram (Fig. 3).

In case of no external loading (Fig. 3a) in the composition of fume gases direct products of combustion take approximately $4 \%$ while in case of a higher loading for the investigated engine (135 Nm) (Fig. 3b), their participation is approx. $20 \%$. Moreover, participation of hazardous substances increases from the level of $0.06 \%$ to $0.75 \%$. 

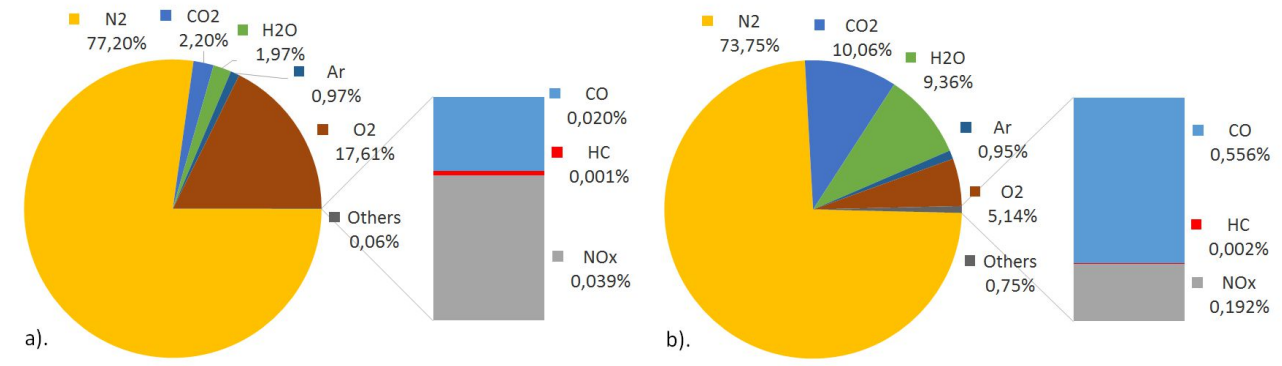

Figure 3. Composition of fumes of AD3.152 engine, a). no loading, $n=760 \mathrm{~min}^{-1}$, b). loading $136 \mathrm{Nm}, \mathrm{n}=1569 \mathrm{~min}^{-1}$

During the initial research and during heating of the engine, it was found out that the combustion process in the investigated engine is related to quite small amounts of carbon monoxide, hydrocarbons and nitric oxide (maximum of $0.75 \%$ ). In relation to the above these components were not included when general expense of fume components was determined. The registered values of the measured fumes components were then used for determination of unit emissions, which were expressed with $\mathrm{g} \cdot \mathrm{kWh}^{-1}$ and presented in figures 4 and 5 with simultaneously determined exploitation characteristics of torque $\mathrm{M}_{\mathrm{o}}$ and mechanical power $\mathrm{N}_{\mathrm{e}}$ of an engine.

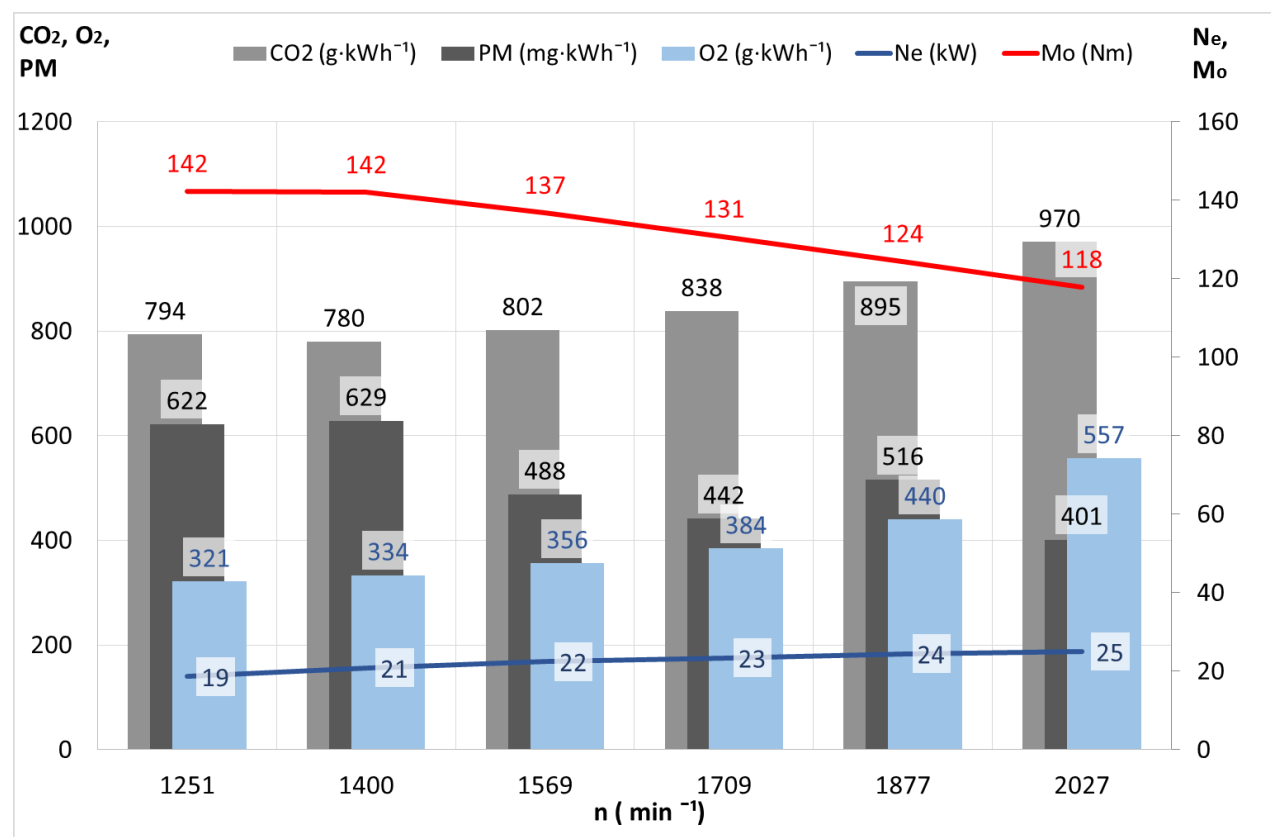

Figure 4. Unit emission of $\mathrm{CO}_{2}, \mathrm{O}_{2}, P M$ and curves of torque $\mathrm{M}_{o}$ and power $\mathrm{N}_{e}$ determined during the load test of AD3.152 engine 
The presented results of measurements and calculations (Fig. 4) show that in the initial stage of the increase of rotational speed to $1400 \mathrm{~min}^{-1}$ unit emission of $\mathrm{CO}_{2}$ decreases but from this value it starts to grow to the speed of $2027 \mathrm{~min}^{-1}$ which corresponds to the maximum power. Within the speed range from $1400 \mathrm{~min}^{-1}$ which corresponds to the maximum moment $\left(142 \mathrm{Nm}\right.$ ) to the speed of $2027 \mathrm{~min}^{-1}$ an increase of unit emission of $\mathrm{CO}_{2}$ by almost $20 \%$ from $780 \mathrm{~g} \cdot \mathrm{kWh}^{-1}$ to $970 \mathrm{~g} \cdot \mathrm{kWh}^{-1}$ took place.

The nature of a unit course of fuel consumption $g_{e}$ is close to the course of unit emission of $\mathrm{CO}_{2}$ (Fig. 5). Thus, one may notice that the scope of rotational speed 1251-1400 $\mathrm{min}^{-1}$ will be favourable from exploitation point of view due to lower fuel consumption.

A reverse trend is with reference to a unit PM emission (Fig.4) and CO (Fig.5). Along with the increase of the rotational speed to $1400 \mathrm{~min}^{-1}$ a unit emission of PM increases slightly but is starts to drop to the speed of $2027 \mathrm{~min}^{-1}$ which corresponds to the maximum power. Within the speed from $1400 \mathrm{~min}^{-1}$ to $2027 \mathrm{~min}^{-1}$ a decrease of unit emission of PM by approx. $36 \%$ took place, from $629 \mathrm{mg} \cdot \mathrm{kWh}^{-1}$ to $401 \mathrm{mg} \cdot \mathrm{kWh}^{-1}$. In case of unit emission of CO a decrease of emission from $25.69 \mathrm{~g} \cdot \mathrm{kWh}^{-1}$ at the speed of $1251 \mathrm{~min}^{-1}$ to the value of $16.90 \mathrm{~g} \cdot \mathrm{kWh}^{-1}$ at the speed of $1877 \mathrm{~min}^{-1}$ is reported. At the speed of $2027 \mathrm{~min}^{-1}$ a unit emission of $\mathrm{CO}$ reaches the value of $16.94 \mathrm{~g} \cdot \mathrm{kWh}^{-1}$.

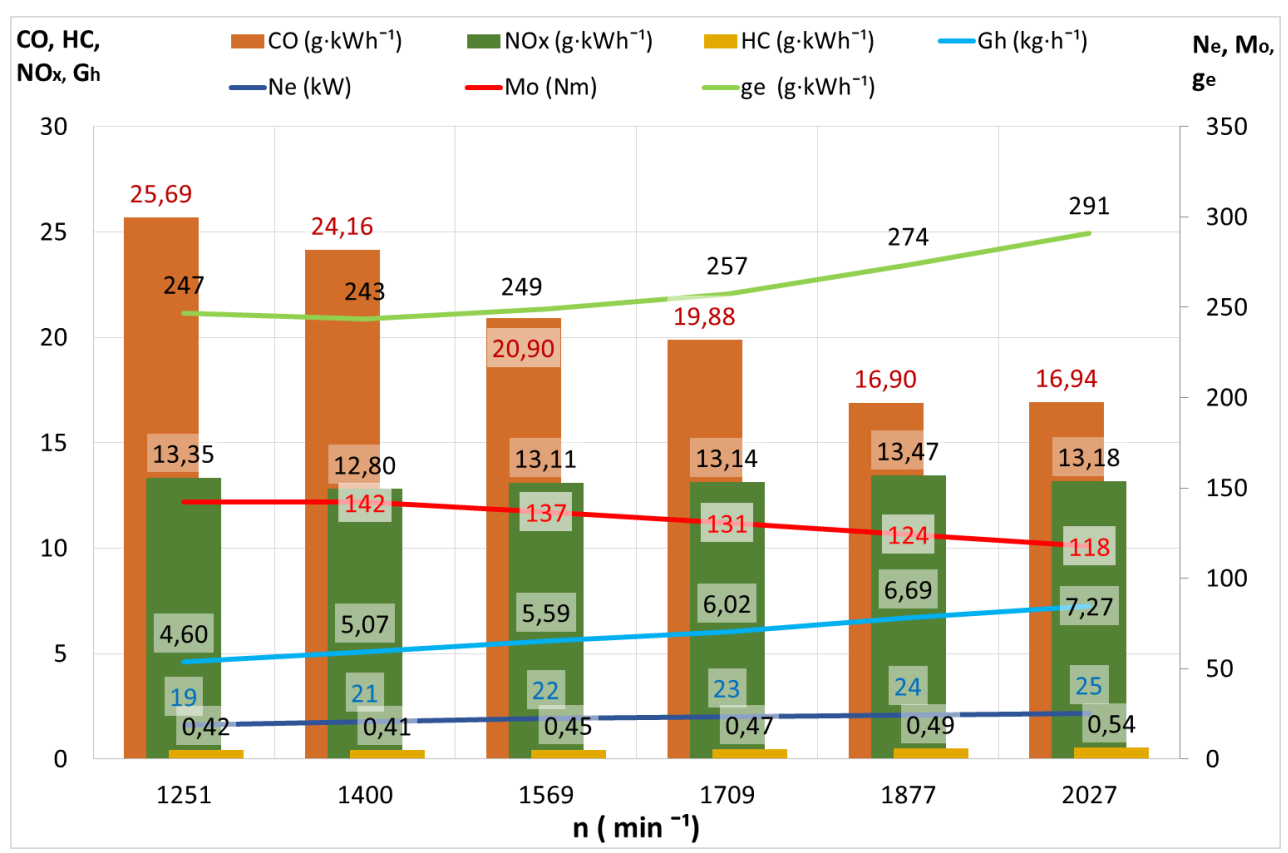

Figure 5. Unit emission of $C O, H C, N O_{X}$ and curves of torque $M_{o}$, power $N_{e}$ and hour $G_{h}$ and unit fuel consumption $g_{e}$ determined during the load test of engine AD3.152

Moreover, one may notice that lower unit emission $\mathrm{CO}_{2}$ (and thus - unit fuel consumption) reported for loads within the rotational speed of an engine 1251-1400 $\mathrm{min}^{-1}$ takes place at the increased unit emission of $\mathrm{CO}$ and PM. Thus, the conclusion that if a given agrotech- 
Emission of fumes...

nical treatment related to high load will be carried out within this scope of speed it will result in lower fuel consumption and lower $\mathrm{CO}_{2}$ emission than if it is carried out within the speeds of 1877-2027 $\mathrm{min}^{-1}$. However, then higher amounts of toxic compounds (CO, PM) will get to the surroundings.

Unit emission of $\mathrm{NO}_{\mathrm{X}}$ does not show significant changes in the function of rotational speed (Fig. 5) and is at the level of approx. $13 \mathrm{~g} \cdot \mathrm{kWh}^{-1}$. It results from the fact that in the discussed case changes of the value of $\mathrm{NO}_{\mathrm{X}}$ participation are proportional to the changes of power $\mathrm{N}_{\mathrm{e}}$ and compensate during calculation of the unit emission.

Analysis of the course of unit changes of HC emission shows that along with the increase of the rotational speed a unit HC emission grows. The increase by $20 \%$ from the value of $0.41 \mathrm{~g} \cdot \mathrm{kWh}^{-1}$ at the rotational speed of $1400 \mathrm{~min}^{-1}$ to the value of $0.54 \mathrm{~g} \cdot \mathrm{kWh}^{-1}$ at the rotational speed of $2027 \mathrm{~min}^{-1}$ is reported.

To refer the obtained results of research to standards which determine limits of emission for combustion engines for non-road usage (Table 2) one should determine that the test covered by standards provide for various scope of loads and periods of their placing and emission is determined as an average value for the entire test.

Table 2 .

Limits of emission of fumes acc., to the standard Stage II for the 8-stage test pursuant to the standard ISO 8178 C1 determined for engines with self-ignition for non-road usage

\begin{tabular}{llrrrc}
\hline $\begin{array}{l}\text { Power } \\
(\mathrm{kW})\end{array}$ & Date & CO & HC & NOx & PM \\
\cline { 3 - 6 } $18 \leq \mathrm{N}_{\mathrm{e}}<37$ & & \multicolumn{4}{c}{$\mathrm{g} \cdot \mathrm{kWh}^{-1}$} \\
\hline
\end{tabular}

On the other hand, the nature of the research described in the paper assumed realization of maximum loads which may take place in exploitation conditions. One may notice that with reference to Stage II, CO emission exceeds considerably the determined level, a similar situation is in case of $\mathrm{NO}_{\mathrm{X}}$, while the results obtained for $\mathrm{HC}$ and $\mathrm{PM}$ are below the limits. With reference to presently applicable standards for new agricultural engines the result of such comparison would be even more unfavourable.

\section{Summary and conclusions}

Based on the research which was carried out on AD3.152 engine it was found out that:

- volumetric participations of $\mathrm{CO}$ and $\mathrm{HC}$ in fumes constitute less than $0.4 \%$ which allows simplification of calculations related to determination of the general expense of fumes,

- calculation of unit emission of the selected components of fumes is possible in given conditions of agricultural engine load based on the suggested methods of research and calculations, 
- the presented methodology of research may be used in case of older structures of engines, which do not have an air flowmeter; however, after insignificant modifications its scope of use may be extended also with modern agricultural engines,

- volumetric participations of particular components of fumes calculated for the load test of AD3.152 engine do not show similar tendencies of changes in the function of rotational speed of an engine as their unit emissions, thus the information itself on the composition of fumes may be insufficient for proper concluding on the scale of emission.

Methodology of research on emission, described by the authors, does not require high financial inputs in comparison to PEMS systems and may be used in case of research on engines used in agriculture, horticulture and forestry.

Limits of emission described in standards (e.g. Stage) show average emissions in tests, which include settled proportions of various states of engine loads, which does not always correspond to the manners of tractors exploitation in a given area. Thus, on account of the nature of tractor loads, which depends on the type of works, emission of fumes should be investigated at the loads corresponding to specific field works. Through the use of research methods and calculations of emission of hazardous components of fumes one may forecast the emission on a given agricultural area in relation to the planned works and the used machinery park.

Polish agriculture is equipped to a great extend in vehicles with engines of old structure and often worn. Thus, they are a source of emission of hazardous fume components at a high level, which considerably exceeds the applicable standard of emission for this type of vehicles (Dieselnet, 2016; Mazanek et al., 2015; Merkisz et al., 2010). Therefore, we should aim at successive replacement of the machinery park in agriculture with more modern and thus more ecological one.

\section{References}

Contributors, W.P.H. (2009). Chapter 3 Tractors and vehicles. Biosystems Engineering, The Wrest Park Story 1924-2006 103, Supplement 1, 3647. Doi:10.1016/j.biosystemseng.2008.11.024.

Dajniak, H. (1985). Ciagniki, Teoria ruchu i konstruowanie. Wydawnictwa Komunikacji i Łączności, Warszawa. ISBN: 83-206-0518-0.

Dieselnet, (2016). Emission Standards: Europe: Nonroad Engines [WWW Document]. URL https://www.dieselnet.com/standards/eu/nonroad.php\#s1 (Accessed 9.16.16).

Gallus, J., Kirchner, U., Vogt, R., Börensen, C., Benter, T. (2016). On-road particle number measurements using a portable emission measurement system (PEMS). Atmospheric Environment 124, Part A, 37-45. Doi:10.1016/j.atmosenv.2015.11.012.

Health Effects Institute. (1995). Diesel Exhaust: A critical analysis of emissions, exposure and health effects. A Special Report of the Institute's Diesel Working Group. (A Special Report of the Institute's Diesel Working Group.). Health Effects Institute, Cambridge, UK.

Huang, C., Lou, D., Hu, Z., Feng, Q., Chen, Y., Chen, C., Tan, P., Yao, D. (2013). A PEMS study of the emissions of gaseous pollutants and ultrafine particles from gasoline- and diesel-fueled vehicles. Atmospheric Environment, 77, 703-710. Doi:10.1016/j.atmosenv.2013.05.059.

Koniuszy, A. (2008). Charakterystyka gęstości czasowej jako podstawowy cykl obciążeń w badaniach ciągników rolniczych. Inżynieria Rolnicza, 12, 181-188. 
Emission of fumes...

Krzaczek, P. (2009). Ocena parametrów energetycznych ciągnika rolniczego JOHN DEERE 6820 z wykorzystaniem diagnostyki pokładowej. Inżynieria Rolnicza, 13, 91-98.

Kuranc, A. (2015). Exhaust emission test performance with the use of the signal from air flow meter. Eksploatacja i Niezawodnosc - Maintenance and Reliability, 17, 129-134. Doi:10.17531/ ein.2015.1.17.

Kuszewski, H., Ustrzycki, A. (2011). Laboratorium spalinowych napedów środków transportu. Oficyna Wydawnicza Politechniki Rzeszowskiej. Rzeszów. ISBN: 83-7199-700-0.

MAHA. (2008). MPM4 Partikelmessgerat. Original-Betriebsanleitung. MAHA Maschinenbau Haldenwang GmbH \& Co. KG.

MAHA. (2006). Hamownia dla pojazdów z watem zdawczym. Typ: ZW500. MAHA Maschinenbau Haldenwang GmbH \& Co. KG.

MAHA. (1999). Motor Gas Tester MGT 5 Five-Gas Tester. Technical Handbook. MAHA Maschinenbau Haldenwang GmbH \& Co. KG.

Mazanek, A., Jakóbiec, J., Krzaczek, P. (2015). Aplikacyjne metody badań jednostek napędowych pojazdów samochodowych i pozadrogowych sektora rolnego. Logistyka, 5, 373-380.

Merkisz, J., Lijewski, P., Fuć, P., Weymann, S., 2013. Exhaust emission tests from non-road vehicles conducted with the use of PEMS analyzers. Eksploatacja i Niezawodnosc-Maintenance and Reliability, 15, 364-368.

Merkisz, J., Lijewski, P., Walasik, S. (2010). The Analysis of Non-road Vehicle Engine Operating Conditions in Terms of Emission Regulations. Eksploatacja i Niezawodnosc - Maintenance and Reliability, 42-48.

Niewiarowski, K. (1983). Tłokowe silniki spalinowe, 3rd ed. Wydawnictwa Komunikacji i Łączności, Warszawa.

Osipowicz, T., Stoeck (2014). Wpływ oleju rzepakowego jako dodatku do paliwa na emisję substancji toksycznych do atmosfery przez silnik ZS. Autobusy, 6, 207-209.

Piekarski, W. (1997). Analiza oddziaływania agregatów ciagnikowych na środowisko przyrodnicze. Wydawnictwo Akademii Rolniczej, Lublin, ISSN 0860-4355.

Podstanicky, I., Liščak, Š., Droździel, P. (2005). Nowoczesna metoda pomiaru zużycia paliwa w transporcie samochodowym. Eksploatacja i Niezawodnosc - Maintenance and Reliability, 25, 16-20.

Pośniak, M., Jankowska, E., Szewczyńska, M., Zapór, L., Brochocka, A., Pietrowski, P. (2010) Zagrożenia spalinami silników diesla. Centralny Instytut Ochrony Pracy - Państwowy Instytut Badawczy, Warszawa.

ZPC URSUS. (1987). Ciagnik URSUS MF235, Instrukcja obsługi. Zrzeszenie Przemysłu Ciągnikowego URSUS, Warszawa, ISBN 978-83-7373-081-6. 


\title{
EMISJA SPALIN CIĄGNIKA URSUS MF235 W WARUNKACH OBCIĄŻENIA Z WYKORZYSTANIEM PRZEWOŹNEGO STANOWISKA DYNAMOMETRYCZNEGO
}

\begin{abstract}
Streszczenie. Artykuł przedstawia obliczenia jednostkowej emisji spalin wykonane na podstawie pomiarów składu spalin podczas testu obciążeniowego. Test realizowano z zastosowaniem przewoźnego stanowiska dynamometrycznego, dostosowanego do badań ciągników rolniczych poprzez wał odbioru mocy (WOM). Obliczenia emisji jednostkowej wykonano na podstawie szacowanego przepływu powietrza zasysanego przez silnik oraz zmierzonego składu spalin emitowanych podczas testu obciążeniowego. Wyniki badań i analiz dostarczają informacji na temat masy cząstek stałych oraz wybranych składników gazowych emitowanych przez silnik pracujący pod obciążeniem, które związane było z jednoczesnym wyznaczaniem charakterystyki eksploatacyjnej silnika. Przedstawiona metodyka może być pomocna przy ocenie oddziaływania ciągników rolniczych na środowisko przyrodnicze w zakresie emitowanych przez nie szkodliwych składników spalin.
\end{abstract}

Słowa kluczowe: emisja spalin, ciągnik rolniczy, testy obciążeniowe silnika, hamownia przewoźna 